\title{
Antifungal, antibacterial and insecticidal potential of Chara schweinitzii (A. Braun) Kützing in Charsadda, Pakistan
}

\author{
Unab Begum ${ }^{1}$, Uzair Ahmad ${ }^{2}$ and Imtiaz Ahmad ${ }^{1}$ \\ 1. Department of Botany, Bacha Khan University, 24420- Charsadda, Pakistan. \\ 2. Department of Plant Protection, The University of Agriculture, 25120- Peshawar, Pakistan \\ *Corresponding author's email: druzair94@gmail.com
}

\section{Citation}

Unab Begum, Uzair Ahmad and Imtiaz Ahmad. Antifungal, antibacterial and insecticidal potential of Chara schweinitzii (A. Braun) Kützing in Charsadda, Pakistan. Pure and Applied Biology. Vol. 6, Issue 1, pp87-96. http://dx.doi.org/10.19045/bspab.2017.60001

Received: 02/11/2016 Revised: $27 / 12 / 2016$ Accepted: 03/01/2017

Online First: 05/01/2017

\section{Abstract}

Various organic solvents were experimented for the screening out of the natural activities of Chara schweinitzii and crude ethanolic extracts. In vitro potential like antifungal activities, antibacterial activities, insecticidal activities and some extracts (n-hexane, chloroform, ethyl acetate, methanol and ethanol) were tested into the experiment. The results of our study showed some major response and vital antifungal activity by the $C$. schweinitzii for the tested fungal species. Disc diffusion and agar well diffusion method was used to test the extract. The experiment was observed, where methanol extracts were inhibited the growth of the used bacteria. Completed tests of $C$. schweinitzii were carefully inspected against the resulted bacterial strains. The impregnated filter paper method process was used for investigation of the insecticidal potential of the algal extracts. The scope of our study is to understand the importance to natural resources (bioactive compounds) for pharmaceutical industry as well as our study is based on the premier findings in Nisatta region, district Charsadda.

Keywords: Antibacterial; Antifungal; C. schweinitzii; Insecticidal

\section{Introduction}

Algae are thought to be a vital character in our society by providing us various bioactive compounds. They create different active metabolites, which are important in pharmaceutical manufacturing [1]. The occurrence of calcium and magnesium carbonate in submerged muddy and watery bottom of the pools and ponds of Charsadda region is in galore. The presence of heavy water in the tested region is also in abundance, which is an excellent characteristic of the Charsadda region for collection of the said specie [2]. The aquatic creatures are also getting the diverse variety of food, shelter and other basic needs through algae [3]. Chara is identified by its macroscopic, multicellular, pro-fusely branched thalloid plant body, generally attains a height of about $20-30 \mathrm{~cm}$ (rarely about 1 meter) and is also differentiated into rhizoid and main axis [4]. Many vital food sources are provided by algae like; certain vitamins, some fatty acids, types of minerals and many polysaccharides. Algae is also important for its verse structure of poisonous and lively compounds for different other substances [5-8]. The plants of chara are of 
great ecological value and highly important. As they are covered with calcium carbonate deposits, they deposit lot of calcium in the bottom of lake, etc., and after a considerable time the whole lake or pond is filled up with calcareous deposits [2]. Many aquatic structures are majorly based on algae, where algae provide them major food sources. $C$. schweinitzii is found in fresh water and belongs to the class; Charophyta. It is cosmopolitan specie and is found worldwide. Chara has some local names which are, "Sand grass, stonewort and musk Grass". Some of them grow in shallow water while most of them grow in deep water from, $4 \mathrm{~cm}$ to $20 \mathrm{~m}$. The chara sticks to the bushy bottom of water, and are not found in oxygenated water or hard water. Their color and size ranges from green to light-gray and $1 \mathrm{~mm}-5 \mathrm{~cm}$ in length, respectively. The branchlets make the whorl of musk grass, which are grouped at continuous linkages. They are easily been differentiated from other species of chara as cortex is absent and are monoecious. The above portion of the water surface covers it which makes the chara highly tolerable and protective into the environment. The need and focus of our study has been made that within the genus chara the condition of monoecism or dioecism is of limited taxonomic significance (especially in the tested region), and that our study reflects only minor variation, and is good sufficient to improve the literature for the genus chara [9]. The key objective of our study was to uncover the buried natural means, which are used in pharmaceutical industry for the benefit of the human beings.

\section{Materials and methods}

\section{Collection sites}

The experiment was performed at the Department of Botany, Bacha Khan University, Charsadda to screen out the biological activities of one of the algal specie " $C$. schweinitzii (A. Braun) Kützing".
The test specie was collected from Nisatta, Charsadda region from fresh shallow water through gloved hands from various small and large freshwater bodies like; canals, small streams and ponds. Our study is based on the methods of Khalid et al. [8].

\section{Algal material}

The experiment was started in September 2014-15 and the algal material was initiated to collect. The material was then brought to the lab, where attached dust, animal dung, external parasitic organisms, aerophytes, litter, insects, algae, spirogyra and sand particles were removed by gloved hands and washed thoroughly with the clean tap water. The major mass of the material was shade dried under the laboratory conditions. After a day, the breakdown of bulky molecules of certain thermo labile natural products initiated. The dried mass was then cut into tiny pieces and weighed on the balance.

\section{Antifungal activities}

Our study included seven fungal species (Figures 1, 2 and 7) which were used to check the antifungal biological activities (Trichophyton longifusus, T. harzianum, Trichoderma hamatum, Rhizoctonia solani, P. oedochilum, Pythium aphanidermatum, Microsporum canis, Fusarium moniliforme, F. oxysporum and Aspergillus flavipes). The agar well diffusion method was used to test the antifungal activity for the above mentioned fungal species. The method for various tests and algal extraction process has been discussed earlier [8].

\section{Antibacterial activities}

The performed test was the in vitro antibacterial bioassay (Figures 3, 4, 5 and 8) which was on the various selected plant extracts against Xanthomonas and Clavibacter michiganensis (Phytopathogenic bacteria) and E. coli (human pathogenic bacteria) performing the disc diffusion method [10]. The numbers of concentrations were two. The Streptomycin sulphate $(1 \mathrm{mg}$ $\mathrm{ml}^{-1}$ ) was among the experiment and was 
used as a positive control while methanol as a negative control. The incubation of the antibacterial assay plates was done at $37{ }^{\circ} \mathrm{C}$ for 24 hours and finally the diameters of the zone of inhibition were measured in $\mathrm{mm}$.

\section{Insecticidal activities}

The impregnated filter paper process was used for investigating the insecticidal potential (Figures 6 and 9) of crude algal extracts [11]. The test was passed in petri plates $(9 \mathrm{~cm}$ diameter) delivered with dual folds of the filter papers. To prepare the test sample, 200mg algal extract (from each extract) was dissolved in $3 \mathrm{ml}$ of methanol solvent. The sensitivity of the experiment was considered and the selection of the insect was done. The well insects (same size) were considered for the experiment.

The sizes of the petri plates were measured and the filter papers were cut of the same size. Double folds of the filter papers were kept inside the sterilized and clean petri plates. The tested sample was transferred on the filter paper. It was then freed so that the filter paper absorbs the solvent. The collected insects (healthy) were put into the petri plate with the help of the clean brush, which were further incubated at $27{ }^{\circ} \mathrm{C}$ into the incubator. The similar method was conducted for every selected insect species into the experiment. For the positive control and negative control, the permethrin and DMSO were used. The checking of the extracts petri plates were observed after a day of incubation and percent mortality for every used extract was find out by the formula:

Percent mortality $=100-$ Number of alive insects in test / Number of alive insects in control $\times 100[8]$.

The insects which were used assess the insecticidal potential of the methanol extracts of algal species are:

Termite and

\section{Tribolium castaneum.}

\section{Results}

The crude ethanolic extract and various organic solvent fractions (ethanolic extracts) were brought into use. Different in vitro activities like; insecticidal activities, antibacterial activities and antifungal activities were conducted.

The crude extract revealed the highest potential (Table 1) against $T$. harzianum with the zone of inhibition $(21 \mathrm{~mm})$, following moderate activity against Pythium $s p$. with the zone of inhibition $(21 \mathrm{~mm})$, Penicillium sp. (19 mm), Fusarium solani (15 $\mathrm{mm})$, Aspergillus flavipes $(17 \mathrm{~mm})$ and Aspergillus niger with the zone of inhibition (12 mm). While the extract showed least activity for Microsporum canis with zone of inhibition (11 mm) (Table 1). The percent inhibition of crude for $T$. harzianum revealed (34.38\%), following Pythium $s p$. (65.62\%), Penicillium sp. (59.25\%), Fusarium solani (46.88\%), Microsporum canis (53.12\%), Aspergillus flavipes (34.38\%), while the least percent inhibition of crude revealed for Aspergillus niger with $(37.5 \%)$. 
Table 1. Growth \% inhibition of $C$. schweinitzii (A. Braun) Kützing against selected fungi strains

\begin{tabular}{|c|c|c|c|c|}
\hline Solvent & Test fungi & $\begin{array}{l}\text { Antifungal } \\
\text { activity of } \\
\text { sample (mm) }\end{array}$ & $\begin{array}{l}\text { Antifungal } \\
\text { activity of } \\
\text { control ( }(\mathbf{m m})\end{array}$ & $\%$ Inhibition \\
\hline \multirow{7}{*}{ Chloroform } & T. harzianum & 21 & 32 & 65.62 \\
\hline & Pythium sp. & 19 & 32 & 59.37 \\
\hline & Penicillium $s p$. & 15 & 32 & 46.88 \\
\hline & Fusarium solani & 19 & 32 & 59.38 \\
\hline & Microsporum canis & 13 & 32 & 40.62 \\
\hline & Aspergillus flavipes & 11 & 32 & 34.38 \\
\hline & Aspergillus niger & 13 & 32 & 40.62 \\
\hline \multirow{7}{*}{ n-hexane } & T. harzianum & 17 & 32 & 53.5 \\
\hline & Pythium sp. & 21 & 32 & 65.75 \\
\hline & Penicillium $s p$. & 20 & 32 & 62.5 \\
\hline & Fusarium solani & 13 & 32 & 40.62 \\
\hline & Microsporum canis & 13 & 32 & 40.75 \\
\hline & Aspergillus flavipes & 10 & 32 & 31.25 \\
\hline & Aspergillus niger & 11 & 32 & 34.38 \\
\hline \multirow{7}{*}{$\begin{array}{l}\text { Crude methanol } \\
\text { extract }\end{array}$} & T. harzianum & 21 & 32 & 65.62 \\
\hline & Pythium sp. & 19 & 32 & 59.25 \\
\hline & Penicillium sp. & 15 & 32 & 46.88 \\
\hline & Fusarium solani & 17 & 32 & 53.12 \\
\hline & Microsporum canis & 11 & 32 & 34.38 \\
\hline & Aspergillus flavipes & 12 & 32 & 37.5 \\
\hline & Aspergillus niger & 12 & 32 & 37.5 \\
\hline \multirow{8}{*}{ Ethyl acetate } & T. harzianum & 20 & 32 & 62.5 \\
\hline & Pythium sp. & 19 & 32 & 59.75 \\
\hline & Penicillium $s p$. & 15 & 32 & 46.87 \\
\hline & Fusarium solani & 11 & 32 & 34.62 \\
\hline & Microsporum canis & 14 & 32 & 43.75 \\
\hline & Aspergillus flavipes & 10 & 32 & 31.25 \\
\hline & Aspergillus niger & 11 & 32 & 34.38 \\
\hline & T. harzianum & 20 & 32 & 62.5 \\
\hline
\end{tabular}




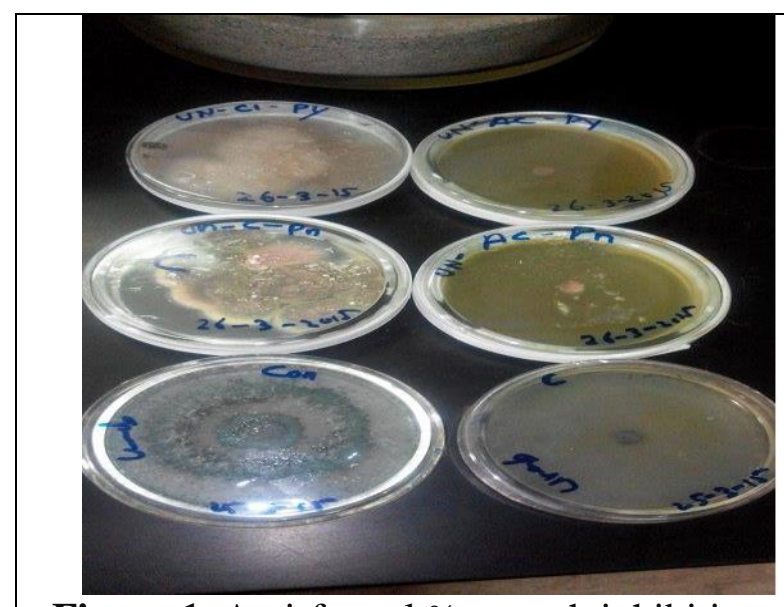

Figure 1. Anti-fungal \% growth inhibition of C. schweinitzii (A. Braun) Kützing in control and crude extracts.

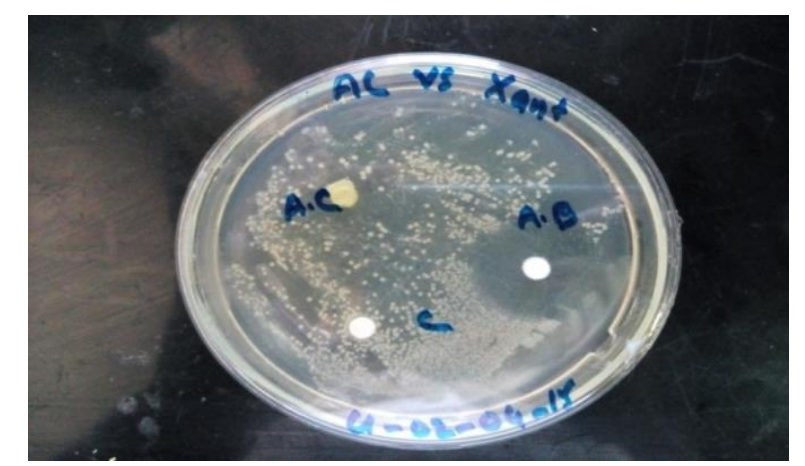

Figure 3. Zone of inhibition and \% inhibition in Xanthomonas campestral.

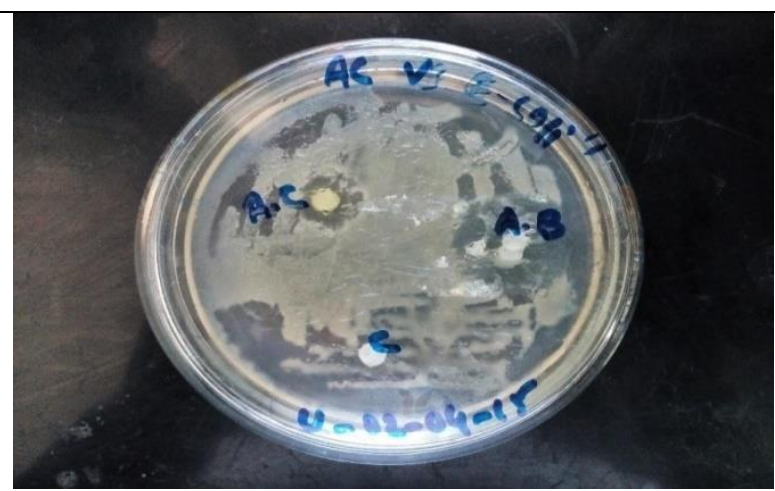

Figure 5. Zone of inhibition and \% inhibition in E. coli.

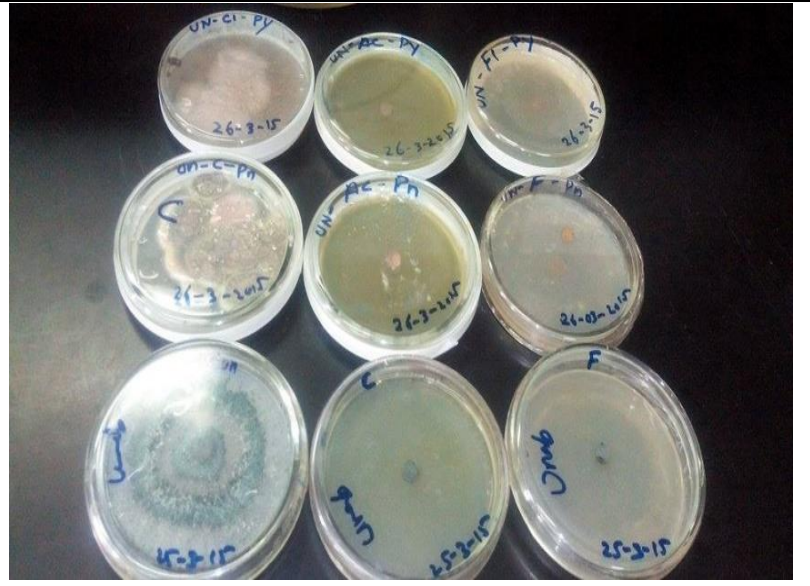

Figure 2. Anti-fungal \% growth inhibition of C. schweinitzii (A. Braun) Kützing in control and crude extracts.

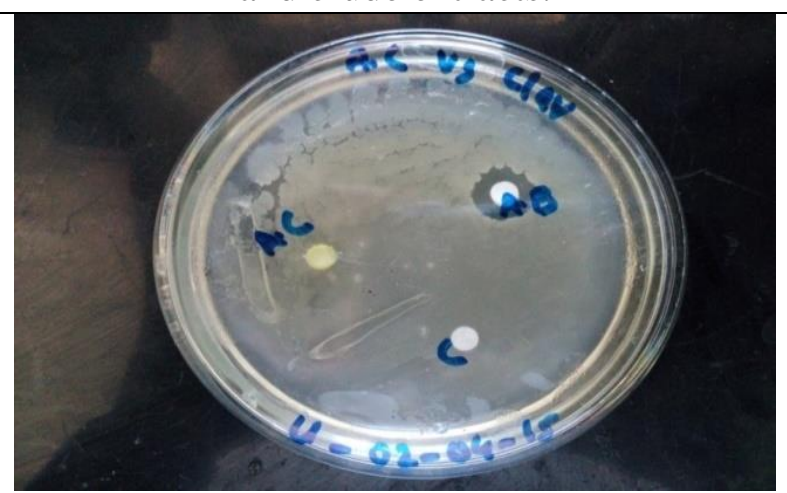

Figure 4. Zone of inhibition and \% inhibition in Clavibacter.

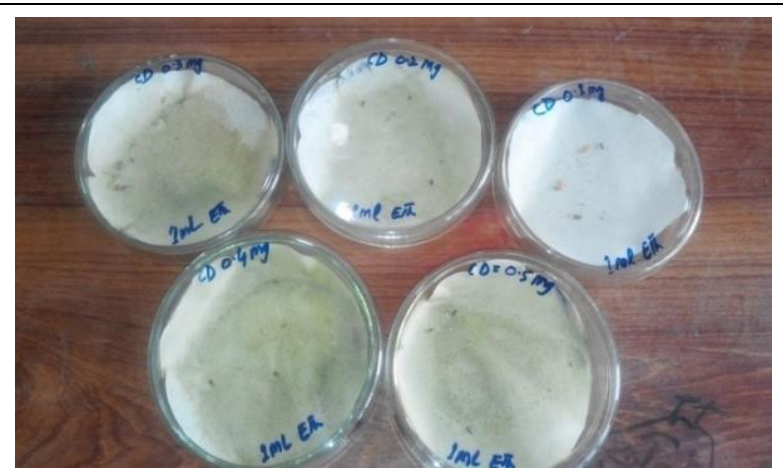

Figure 6. Insecticidal activity of the aqueous solution against Tribolium castaneum. 


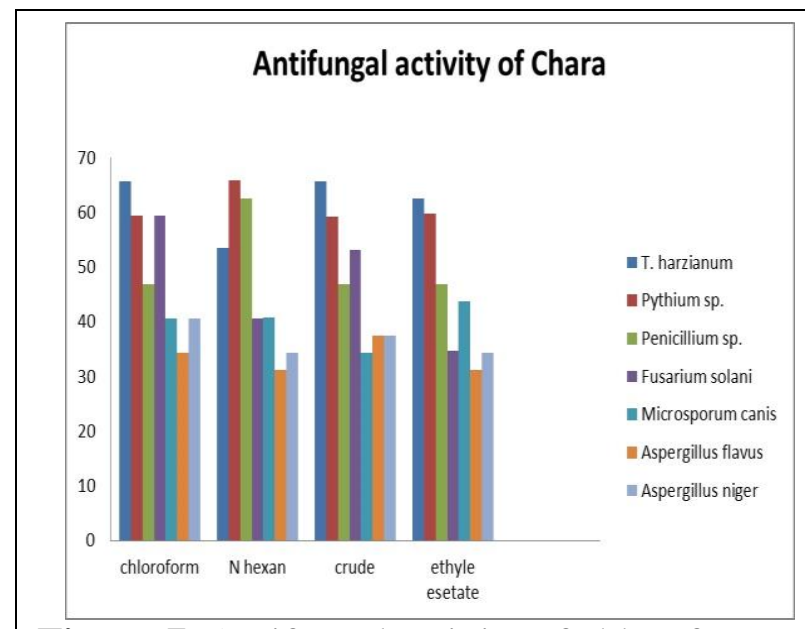

Figure 7. Antifungal activity of chloroform, nhexane, crude and ethyl acetate against the selected strains of chara.

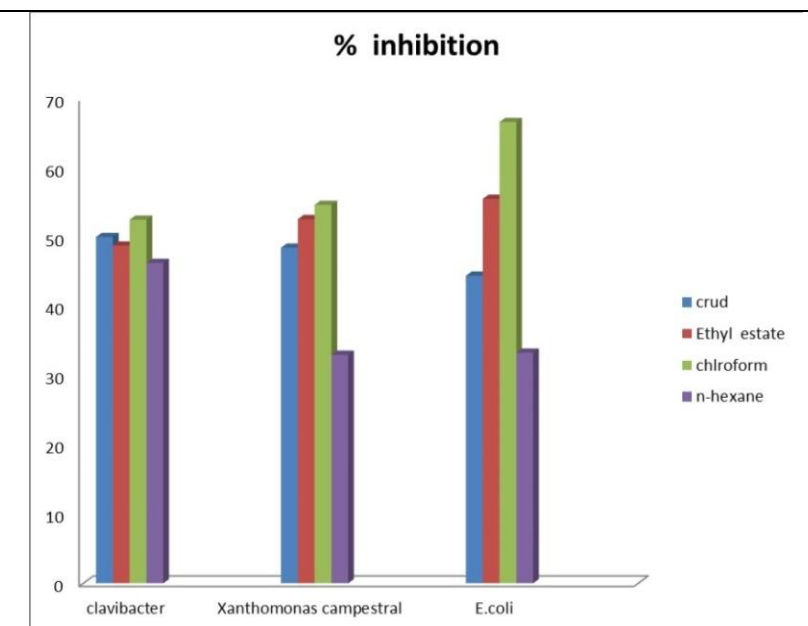

Figure 8. Antibacterial \% inhibition of E. coli, $X$. campestral and clavibacter against the selected strains of chara.

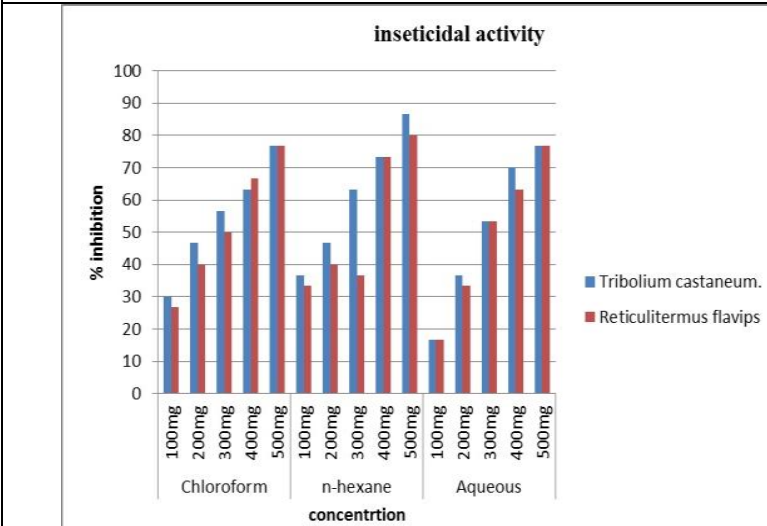

Figure 9. Insecticidal activity of n-hexane, chloroform and aqueous solution against $T$. castaneum and $R$. flavipes.

The greatest activity was revealed by the chloroform extract for $T$. harzianum, with the zone of inhibition $(21 \mathrm{~mm})$. The moderate activity was shown by Pythium $s p$. with $(19 \mathrm{~mm})$, followed by Penicillium $\mathrm{sp}$. (15 mm), Fusarium solani (19 mm), Microsporum canis (13 $\mathrm{mm})$ and Aspergillus niger $(13 \mathrm{~mm})$. While the least activity was revealed by Aspergillus flavipes with the zone of inhibition $(11 \mathrm{~mm})$ (Table $1)$.

The n-hexane extract revealed maximum activity for Pythium sp. with the zone of inhibition $(21 \mathrm{~mm})$ while the moderate activity was revealed by $T$. harzianum (17 $\mathrm{mm})$, Penicillium sp. (21 mm), Fusarium solani (20 mm), Microsporum canis (13 $\mathrm{mm})$ and Aspergillus niger (13 $\mathrm{mm})$, while the least potential was revealed by Aspergillus flavipes with the zone of inhibition (10 mm).

The ethyl acetate extract demonstrated greatest activity for $T$. harzianum with the zone of inhibition (20 mm), while moderate potential for Pythium sp. (19 mm), Penicillium sp. (15 mm), Fusarium solani (11 $\mathrm{mm})$, Microsporus canis $(14 \mathrm{~mm})$ and Aspergillus niger with the zone of inhibition (11 $\mathrm{mm})$, while the least potential was showed against Aspergillus flavipes with the 
zone of inhibition (10 mm). Our study is in line with the experiment of Mahadevi et al. [9].

The antibacterial examinations to find out the extracts of $C$. schweinitzii were tested against various bacterial strains (Table 2). The zone of inhibition for clavibacter revealed $(17 \mathrm{~mm})$, followed by ethyl acetate (21 $\mathrm{mm})$, chloroform $(22 \mathrm{~mm})$, while the least was revealed against n-hexane (20 $\mathrm{mm})$. The zone of inhibition for Xanthomonas campestral revealed (0.47 $\mathrm{mm})$, followed by ethyl acetate $(0.51 \mathrm{~mm})$, chloroform $(0.53 \mathrm{~mm})$, while the least was showed against $\mathrm{n}$-hexane $(0.32 \mathrm{~mm})$. The zone of inhibition for $E$. coli crude was revealed $(0.40 \mathrm{~mm})$, followed by ethyl acetate $(0.50 \mathrm{~mm})$, chloroform $(0.60 \mathrm{~mm})$, while the least was revealed against nhexane with the zone of inhibition $(0.30$ $\mathrm{mm})$.

The percent inhibition in crude for clavibactor was recorded $(50 \%)$, followed by ethyl acetate (48.75\%), chloroform $(52.5 \%)$, while the least percent inhibition was recorded for n-hexane $(46.25 \%)$. The percent inhibition for Xanthomonas campestral in crude extract revealed (48.45\%), followed by ethyl acetate (52.57\%), chloroform (54.63\%), while for nhexane it revealed $(32.98 \%)$. The percent inhibition of $E$. coli for crude extract revealed $(44.4 \%)$, followed by ethyl acetate $(55.5 \%)$, chloroform $(66.6 \%)$ while in $n-$ hexane it revealed $(33.3 \%)$.

Table 2. Zone of inhibition and \% inhibition of antibacterial bioassay of the test insects

\begin{tabular}{|c|c|c|c|c|c|c|}
\hline Treatments & \multicolumn{6}{|c|}{ Test species } \\
\hline & \multicolumn{2}{|l|}{ Clavibacter } & \multicolumn{2}{|c|}{ Xanthomonas campestral } & \multicolumn{2}{|l|}{ E. coli } \\
\hline & $\begin{array}{l}\text { Zone of } \\
\text { inhibition (cm) }\end{array}$ & $\begin{array}{l}\% \\
\text { Inhibition }\end{array}$ & $\begin{array}{l}\text { Zone of } \\
\text { inhibition }(\mathrm{cm})\end{array}$ & $\begin{array}{l}\text { \% } \\
\text { Inhibition }\end{array}$ & $\begin{array}{l}\text { Zone of } \\
\text { inhibition }(\mathbf{c m})\end{array}$ & $\begin{array}{l}\% \\
\text { Inhibition }\end{array}$ \\
\hline -ve control & 0 & - & 0 & - & 0 & - \\
\hline +ve control & $0.8 \pm 0.10$ & - & $0.97 \pm 0.25$ & - & $0.90 \pm 0.01$ & - \\
\hline Crude & $0.40 \pm 0.10$ & 50 & $0.47 \pm 0.06$ & 48.45 & $0.40 \pm 0.01$ & 44.4 \\
\hline Ethyl acetate & $0.39 \pm 0.01$ & 48.75 & $0.51 \pm 0.08$ & 52.57 & $0.50 \pm 0.01$ & 55.5 \\
\hline Chloroform & $0.42 \pm 0.12$ & 52.5 & $0.53 \pm 0.07$ & 54.63 & $0.60 \pm 0.02$ & 66.6 \\
\hline n-hexane & $0.37 \pm 0.10$ & 46.25 & $0.32 \pm 0.01$ & 32.98 & $0.30 \pm 0.04$ & 33.3 \\
\hline
\end{tabular}

The insecticidal activities of crude methanolic extracts in chloroform, n-hexane and aqueous were conducted by screening technique against Tribolium castaneum and Reticulitermus flavipes (Table 3). The T. castaneum and $R$. flavipes were selected as the test insects. The crude extracts and the fractions revealed noteworthy insecticidal potential for both the tested insects. The crude extracts and fraction revealed dose dependent potential.

Results revealed (Table 3) important percent lethality for the tested insect (T. castaneum). Our data showed the highest percent lethality in chloroform $(76.67 \%)$ at $(500 \mathrm{mg})$ while the least percent lethality revealed
$(30.00 \%)$ at $(100 \mathrm{mg})$. The percent lethality revealed at (200mg), (300mg), (400mg) were $(46.67 \%),(56.67 \%)$ and $(63.33 \%)$, respectively. Our data showed the highest percent lethality for n-hexane $(86.67 \%)$ at (500mg) while the least percent lethality was revealed $(36.67 \%)$ at $(100 \mathrm{mg})$. The percent lethality revealed at $(200 \mathrm{mg}),(300 \mathrm{mg})$, $(400 \mathrm{mg})$ revealed $(46.67 \%),(63.33 \%)$ and $7(3.33 \%)$, respectively.

Our results declared important percent lethality for the test insect (T. castaneum). Our data revealed the highest percent lethality in aqueous $(76.67 \%)(500 \mathrm{mg})$ while the least was revealed at $(100 \mathrm{mg})$ which is $(16.67 \%)$. The percent lethality revealed at 
(200mg), (300mg) and (400mg) was $(36.67 \%), \quad(53.33 \%)$ and $(70.00 \%)$, respectively. Results (Table 4) revealed the important percent lethality for the test insect (R. flavipes). Our data revealed the greatest percent lethality for chloroform (76.67\%) at (500mg) while the least was revealed at (100mg) which is $(26.67 \%)$. The percent insecticidal lethality against $T$. castaneum revealed $(40.00 \%)$ at $(200 \mathrm{mg})$, followed by
$(50.00 \%)$ at $(300 \mathrm{mg})$ and $(66.67 \%)$ at (400mg). Results (Table 4) revealed the significant percent lethality against the test insect ( $R$. flavipes). Our data revealed the greatest percent lethality for n-hexane $(80.00 \%)$ at $(500 \mathrm{mg})$ while the least percent lethality revealed $(33.33 \%)$ at $(100 \mathrm{mg})$. The percent lethality at $(200 \mathrm{mg})$ revealed $(40.00 \%)$, followed by $(36.67 \%)$ at $(300 \mathrm{mg})$ and $(73.33 \%)$ at $(400 \mathrm{mg})$.

Table 3. Insecticidal activity against Tribolium castaneum

\begin{tabular}{|c|c|c|c|c|c|c|c|c|c|}
\hline S. No & Extracts & $\begin{array}{l}\text { Conc. } \\
\text { (mg) }\end{array}$ & $\begin{array}{l}\text { Total no. } \\
\text { of insects }\end{array}$ & $\begin{array}{l}\text { No. of dead } \\
\text { insects }\end{array}$ & $\begin{array}{l}\text { No. of alive } \\
\text { insects }\end{array}$ & $\begin{array}{l}\% \\
\text { Lethality }\end{array}$ & LCL & UCL & $\mathbf{L D}_{\mathbf{5 0}}$ \\
\hline \multirow{5}{*}{1} & \multirow{5}{*}{$\begin{array}{l}\text { Chlorofor } \\
\text { m }\end{array}$} & 100 & 30 & 9 & 21 & 30.00 & \multirow{5}{*}{144.53} & \multirow{5}{*}{295.72} & \multirow{5}{*}{219.97} \\
\hline & & 200 & 30 & 14 & 16 & 46.67 & & & \\
\hline & & 300 & 30 & 17 & 13 & 56.67 & & & \\
\hline & & 400 & 30 & 19 & 11 & 63.33 & & & \\
\hline & & 500 & 30 & 23 & 7 & 76.67 & & & \\
\hline \multirow{5}{*}{2} & \multirow{5}{*}{ n-hexane } & 100 & 30 & 11 & 19 & 36.67 & \multirow{5}{*}{115.35} & \multirow{5}{*}{231.16} & \multirow{5}{*}{178.58} \\
\hline & & 200 & 30 & 14 & 16 & 46.67 & & & \\
\hline & & 300 & 30 & 19 & 11 & 63.33 & & & \\
\hline & & 400 & 30 & 22 & 8 & 73.33 & & & \\
\hline & & 500 & 30 & 26 & 4 & 86.67 & & & \\
\hline \multirow{5}{*}{3} & \multirow{5}{*}{$\begin{array}{l}\text { Aqueous } \\
\text { solution }\end{array}$} & 100 & 30 & 5 & 25 & 16.67 & \multirow{5}{*}{260.48} & \multirow{5}{*}{320.82} & \multirow{5}{*}{260.48} \\
\hline & & 200 & 30 & 11 & 19 & 36.67 & & & \\
\hline & & 300 & 30 & 16 & 14 & 53.33 & & & \\
\hline & & 400 & 30 & 21 & 9 & 70.00 & & & \\
\hline & & 500 & 30 & 23 & 7 & 76.67 & & & \\
\hline
\end{tabular}

Table 4. Insecticidal activity against Reticulitermus flavipes

\begin{tabular}{|c|c|c|c|c|c|c|c|c|c|}
\hline S. No & Extracts & $\begin{array}{l}\text { Conc. } \\
\text { (mg) }\end{array}$ & $\begin{array}{l}\text { Total no. } \\
\text { of insects }\end{array}$ & $\begin{array}{l}\text { No. of dead } \\
\text { insects }\end{array}$ & $\begin{array}{l}\text { No. of alive } \\
\text { insects }\end{array}$ & $\begin{array}{l}\% \\
\text { Lethality }\end{array}$ & LCL & UCL & $\mathbf{L D}_{50}$ \\
\hline \multirow{5}{*}{1} & \multirow{5}{*}{ Chloroform } & 100 & 30 & 8 & 22 & 26.67 & \multirow{5}{*}{179.72} & \multirow{5}{*}{321.74} & \multirow{5}{*}{245.51} \\
\hline & & 200 & 30 & 12 & 18 & 40.00 & & & \\
\hline & & 300 & 30 & 15 & 15 & 50.00 & & & \\
\hline & & 400 & 30 & 20 & 10 & 66.67 & & & \\
\hline & & 500 & 30 & 23 & 7 & 76.67 & & & \\
\hline \multirow{5}{*}{2} & \multirow{5}{*}{ n-hexane } & 100 & 30 & 10 & 20 & 33.33 & \multirow{5}{*}{112.11} & \multirow{5}{*}{502.59} & \multirow{5}{*}{237.37} \\
\hline & & 200 & 30 & 12 & 18 & 40.00 & & & \\
\hline & & 300 & 30 & 11 & 19 & 36.67 & & & \\
\hline & & 400 & 30 & 22 & 8 & 73.33 & & & \\
\hline & & 500 & 30 & 24 & 6 & 80.00 & & & \\
\hline \multirow{5}{*}{3} & \multirow{5}{*}{$\begin{array}{l}\text { Aqueous } \\
\text { solution }\end{array}$} & 100 & 30 & 5 & 25 & 16.67 & \multirow{5}{*}{220.50} & \multirow{5}{*}{343.32} & \multirow{5}{*}{274.99} \\
\hline & & 200 & 30 & 10 & 20 & 33.33 & & & \\
\hline & & 300 & 30 & 16 & 14 & 53.33 & & & \\
\hline & & 400 & 30 & 19 & 11 & 63.33 & & & \\
\hline & & 500 & 30 & 23 & 7 & 76.67 & & & \\
\hline
\end{tabular}




\section{Discussion}

Our study is in line with the experiment of Hadia et al. [12], who assessed antibacterial (Enterobacter, Micrococcus luteus, Pseudomonas aeruginosa and E. coli) and antifungal activities in various solvents benzene, chloroform and ethanol extract. Datura stramonium of chloroform extract produced maximum zone of inhibition and ethanol extract of $D$. stramonium gave maximum zone of inhibition against $K$. pneumonia while minimum against $E$. coli. Results further revealed that chloroform extract was very active against $S$. aureus, $P$. aeruginosa and $M$. luteus. All the extracts of D. stramonium have shown significant antifungal activity against Saccharomyces cerevisiae, Aspergillus fumigatus and Aspergillus niger with maximum antifungal activity against $S$. cerevisiae and zone of inhibition was about $16 \pm 0.2 \mathrm{~mm}$ by ethanol extract, $15 \pm 0.3 \mathrm{~mm}$ by chloroform and $14 \pm 1.6 \mathrm{~mm}$ by benzene extract while minimum antifungal activity was observed against $A$. niger.

Our study is also parallel to the experiments of Daljit K [13], who screened antimicrobial activities of the aqueous solution of the Moringa oleifera against two yeast strains, three Gram positive and seven Gram negative bacteria by agar well diffusion assay. Results concluded that the MICs of seed coat, stem bark and pod's husks ranged from $0.5-1.25 \mathrm{mg} \mathrm{ml}^{-1}, 3.0-4.2 \mathrm{mg} \mathrm{ml}^{-1}$ and 4.0-5.6 $\mathrm{mg} \mathrm{ml}^{-1}$, respectively. Both seeds' coat and pods' husks extracts exhibited microbicidal properties which were totally inhibited for 12 hours, respectively. Seeds' coat extract was the most effective against E. coli, while some pathogens, treated with stem bark extract, exhibited regrowth again after 24 hours apparently.

Our study was involved in antifungal activity, which is in line with the study of Paola et al. [14] who evaluated the extracts of antifungal activities of 10 plant species against the phyto pathogenic fungus Alternaria sp. Their study determined minimal inhibitory concentration (MIC) and minimum fungicidal concentration (MFC). Results revealed that the MIC values ranged between 1.25 and $25 \mu \mathrm{g} \mathrm{mL} \mathrm{m}^{-1}$. The MFC values of the extracts ranged between $1.25 \mu \mathrm{g} \mathrm{mL}^{-1}$ (Rosmarinus officinalis L.) and $10 \mu \mathrm{g} \mathrm{mL}^{-1}$ (Cynara scolymus L.). MICs and MFCs values obtained from leaves (Salvia officinalis and $R$. officinalis) and seeds extracts (Salvia sclarea L.) were quite comparable to values obtained with the conventional fungicide captan $\left(2.5 \mu \mathrm{g} \mathrm{mL}^{-1}\right)$. The extracts of Salvia sclarea, S. officinalis and $R$. officinalis could be considered as potential sources of antifungal compounds for treating diseases in plants. These extracts showed maximum activity, even at very low concentrations, and the same fungicide effects as chemical fungicide.

\section{Conclusion}

Our experiment exposed the biological activities and nutraceutical profile of the algae "C. schweinitzii (A. Braun) Kützing". The physiochemical study of the said algae into our experiment showed the occurrence of some important elements. Our results of biological potential of $C$. schweinitzii (A. Braun) Kützing crude methanol extract and various plant extracts (methanol extracts) revealed the $C$. schweinitzii (A. Braun) Kützing includes some vital insecticidal activities, antibacterial, phytotoxic, cytotoxic and antifungal and is resulted that C. schweinitzii (A. Braun) Kützing has a greater amount of nutrition as well as offers strong biological activities.

\section{Authors' contributions}

Conceived and designed the experiments: $U$ Begum, Performed the experiments: U Begum, Contributed reagents/materials and analysis tools: U Begum, Analysis of data: U Ahmad \& I Ahmad, Wrote the paper: U Ahmad, Data collection: U Ahmad 


\section{Acknowledgement}

The author is immensely grateful to Uzair Ahmad (Research Associate) for his advice, write up, guidance, assistance, encouragement and inspiration.

\section{References}

1. Aslam S \& Ayub WK (2001). Genus Chara: Usefulness of genus Chara, Biology. Intel Biological forum 223-230.

2. Daljit K (2013). Antimicrobial activity of Moringa oleifera from different locations against some human pathogens. Academia J Medicinal Plants 1(5): 080091.

3. Ghazala N \& Johnson J (2012). Testing the various species and assays on phycochmistry and biological activity of Spirogyre rhizoides. American $J$ Bot 12(9): 345-361.

4. Hadia G, Rubina NQ, Muhammad AK, Shazia H \& Nabila Y (2012). Antibacterial and antifungal activity of different extracts of Datura stramonium (branches and leaves sample). J Biotech and Pharma Res 3(9): 141-148.

5. Khalid MN, Shameel M, Ahmad VU, Shahzad S \& Leghari SM (2011). Studies on the bioactivity and phycochemistry of Microcystis aeruginosa (Cyanophycota) from Sindh. Pak J Bot 42: 2635-2646.

6. Mahadevi B \& John PLJ (2014). Distribution and seasonal variation of some Caulerpa species (Green seaweed) in Thoothukudi region, The south east coast of tamil nadu, India. Intel J Pure \& App Biosci 2(3): 135-138.

7. Neelesh T (1997). Chara: Occurrence, Features and Reproduction. Intel Biological forum 133-141.
8. Naqvi SBS, Sheikh D, Usmanghani K, Shameel M \& Sheikh R (1992). Screening of marine algae of Karachi for haemo glutinin activity. Pak J Pharm Sci 5: 129-138.

9. Naila B, Ghazala B, Shameel M, Choudhary MI \& Leghari SM (2005). Phycochemistry and bioactivity of Lyngbya (Nostocophyceae shameel) from Sindh. Intel J Phycol Phycochem 1: 125134.

10. Oswald T (1999). Economic Botany: Botanical society of America 53(3): 353354.

11. Paola DD, Andrea C, Diego A, Patricia L, Fernando F \& Marco DR (2011). Antifungal activity of medicinal plant extracts against phyto pathogenic fungus Alternaria sp. Chilean J Agric Res 71(2): 231-239.

12. Priya TS, Suganthi R, Saranya A \& Thangaraj K (2013). Relationship between plasmid occurrence and antibiotic resistance in Myroides odoratimimus SKS05-GRD isolated from raw chicken meat. World J Microbiol Biotech 29: 983-990.

13. Rania \& Hala (2008). Antibacterial and antifungal activity of cyanobacteria and green microalgae: Evaluation of medium components by Placket burman design for antimicrobial activity of Spirulina platensis. GJBBR 3: 22-31.

14. Shahnaz L, Ghazala B \& Shameel M (2006). Phyco chemistry and bioactivity of Enteromorpha intestinalis (Ulvophyceae: Charophyta) from Sindh, Pakistan. Intel J Phycol Phycochem 2: 59-62. 